\title{
Value added knowledge by prosumers in Poland and the UK specifically for service process stages
}

Roisin Mullins, Faculty of Business and Management, University of Wales Trinity Saint David, United Kingdom, r.mullins@uwtsd.ac.uk

Monika Eisenbardt, Faculty of Finance and Insurance, University of Economics in Katowice, Poland, monika.eisenbardt@ue.katowice.pl

Sandra Dettmer, Faculty of Business and Management, University of Wales Trinity Saint David, United Kingdom, s.dettmer@uwtsd.ac.uk

Ewa Ziemba, Faculty of Finance and Insurance, University of Economics in Katowice, Poland, ewa.ziemba@ue.katowice.pl

\begin{abstract}
The purpose of the paper is to advance research on knowledge sharing by prosumers with enterprises and public organizations by examining and better understanding what knowledge about improving services, prosumers currently share and would like to share in future. The paper verifies a proposed theoretical framework by showing those service knowledge items that prosumers can share with enterprises and public organizations. The reported outcomes result from a survey that yielded responses by 171 prosumers from the United Kingdom (UK) and 783 from Poland. The research findings describe the differences between prosumers in Poland and the UK, both in their current knowledge sharing experiences and their desired future knowledge sharing. The analysis of the results shows that in general prosumers would like to share knowledge more widely than they are sharing currently. Furthermore, the findings show that Polish prosumers currently share knowledge marginally more than their counterparts in the UK. Should they be given the opportunity Poland-based prosumers would like to share knowledge more widely than their UK-based counterparts. In particular the results reveal that both in Poland and the UK, prosumers want to engage with enterprises in sharing knowledge relevant to the ordering process and the customer services process. This finding is relevant to any enterprises that may like to engage prosumers in providing feedback about their service offerings.
\end{abstract}

Keywords: Consumer knowledge, prosumer, knowledge sharing, services development, Poland, UK.

\section{Introduction}

The contemporary e-business environment consists of various technologies and integrated technology platforms accessed through business web sites that are designed to enable active customer's engagement in a variety of roles that impact on the business processes including designing and delivering business services to reach the consumer market (Aghamirian, Dorri, \& Aghamirian, 2013; Bendapudi \& Leone, 2003; Troye, Xie, \& Breivik, 2002). This customer 
involvement in the design and delivery of services is achieved through knowledge sharing. Interestingly, the services co-created by the consumer may be consumed simultaneously which is a different approach, as it alters the value offer in the creation and production of services. The influence from the consumer is increased when there is this level of concurrency not only seen by the enterprises with which they share comments, commit time, and creativity but also with other consumers who have a similar goal in sharing knowledge (Löcker et al., 2014). Authors such as Calosci (2017) have documented a change in the relationship that consumers have with businesses and this is explicit in several areas of collaborative production such as, exhibition design and collaborative software development at hackathons as well as with experiences that are linked to the social economy in particular.

New technological development has changed the way businesses compete against one another ultimately forcing a business to rethink their traditional strategies and e-business processes. The business model at the heart of the corporate strategy considers the value offering and has the ability to inform the strategy, to explore how it intends to take advantage of new opportunities driven by what is valued by the customer (Osterwalder \& Pigneur, 2002). Furthermore, some theorists consider that business models are the missing link that unites strategy and the effective execution of relevant and efficient business and service processes (Osterwalder \& Pigneur, 2013).

Enterprises that innovate and adapt to e-business demands (Boyle, 2010) by improving the integration of systems to meet customer demands may be able to free-up resources to manage customer service, market the business globally to sell goods and services (Lobel, 2017). The improved efficiency and transparency (Franco \& Bulomine, 2016) and higher degrees of automation may add value to services which are pivotal for organizations to maintain competitive advantage (Postolov et al., 2014). Value-co-creation is considered to be a further paradigm shift that enterprises may distinguish as a strategic goal to emphasize the engagement or more significantly the inclusion of customers in the value creation process to understand their needs, desires and preferences (Lusch \& Vargo 2006; Payne, Storbacka, \& Frow, 2008). It is this focus on external knowledge that adds value to the service process stages since the value chain interactions between enterprise, supplier and customer include interactions in addition to the transaction stage (Prahalad \& Ramaswamy, 2004). Value creation in the practice of co-creating and co-existing (Ritzer \& Jurgenson, 2010; Tapscott \& Williams, 2006) is central to establish the synchronized actions associated with knowledge sharing in the creation and delivery of services.

Therefore, it is proposed that those consumers who actively participate in a knowledge exchange process, which can be explained as a discourse between an enterprise and various consumers to share knowledge with the enterprise and other consumers are described as prosumers. The term prosumer is directly connected with a prosumption term which means the process in which prosumers actively share knowledge with enterprises or other prosumers (Bylok, 2013; Fine, Gironda, \& Petrescu, 2017; Hernández-Serrano, Renés-Arellano, Graham, \& Greenhill, 2017; Rayna \& Striukova, 2016; Ritzer \& Jurgenson, 2010; Tapscott \& Williams, 2006; Xie, Bagozzi, $\&$ Troye, 2008). Prosumers' activities are also referred to as the activities undertaken to produce new products and services of value for enterprises, as well as for themselves (Ziemba, Eisenbardt, Mullins, \& Grabara, 2018). 
The prosumer literature illustrates how Toffler (1980) acknowledged that the customers can fulfill a dual role that of producer and consumer and that dual role is crucial for modern enterprises' performance and development of their services as more enterprises focus on external sources of knowledge as an external source of ideas and innovations. Nevertheless, few academics focus on the potential of employing external knowledge sources in creating and developing novel services among which prosumers' knowledge has become more essential in explicit knowledge sharing (Cui \& Wu, 2015; Geri, Gafni, \& Bengov, 2017; Panni, 2015; Taherparvar, Esmaeilpour, \& Dostar, 2014).

The focus on interaction with prosumers have long been expected to be a part of the enterprise strategy (Pine et al., 1995). Despite the wealth of literature on knowledge management, and more specifically customer knowledge management as well as the increasingly growing literature on prosumption, business processes development and prosumers knowledge remains largely unexplored and poorly understood and concerns the complex multidimensional and dynamic nature of customer engagement (Brodie, Llic, Juric, \& Hollebeek, 2013). Some researchers have considered that efficient business processes management are crucial for enterprises and could bring rational consequences where the processes seek to involve consumer collaboration (Aghamirian, Dorri, \& Aghamirian, 2015; Trejo, Gutiérrez, \& Guzman, 2016).

For modern enterprises knowing the prosumer is valued as a strategic advantage which helps them maintain their market competitiveness, as well as, invest in the customer communications. This knowledge sharing leads to prosumers being 'locked in' to the value chain leading to higher switching costs and may continue to develop themselves to become more responsive to customer needs (Aghamirian, Dorri, \& Aghamirian, 2013; Brabham, 2012; Song \& Kang, 2016; Tsai, Tsai, Li, \& Lin, 2012; Tseng, 2016). The concentration on value added knowledge from external actors such as 'customers' external knowledge is a valuable strategic intangible asset for enterprises and improves their competitive position (Planells, 2015; Ziemba \& Mullins, 2016).

Prosumers participate in the process of co-creation or even co-production of services (Ritzer \& Jurgenson, 2010; Tapscott \& Williams, 2006) as they share knowledge about the services they use and experience. Thus, they play a substantial role in the whole service life cycle. Consequently, prosumers' knowledge can be embedded into the business process. Detailed analyses showed that their knowledge can lead to development of new products, upgrading of existing products or improvements of the products (Ziemba et al., 2018). Likewise, their knowledge sharing may lead to the development of services and in turn could aid those business processes that relate to service developments, upgrading and improvement of existing services. Ziemba and Eisenbardt (2015a) explained the basis of the APQC Process Classification Framework (APQC, 2016), and suggested a conceptual framework of prosumers participation in business processes. In their paper they focus on four operational processes in which prosumers' knowledge can be notably used. What is more, they did not differentiate between product and service-processes. These business processes (BP) are: Process 2.0 Develop and Manage Products and Services; Process 3.0 Market and Sell Products and Services; Process 4.0 Deliver Products and Services; and Process 5.0 Manage Customer Service. Their research indicated among others that prosumers are willing to share knowledge for the development of services including market and selling, delivery and customer services (Ziemba \& Eisenbardt, 2017). 
Table 1 indicates the types of services development knowledge that prosumers can share with enterprises.

Table 1. Types of Knowledge which Prosumers May Share About Services (APQC, 2016;

Ziemba \& Eisenbardt, 2015a)

\begin{tabular}{|l|l|l|}
\hline Operational Business Processes & Item & Kind of knowledge \\
\hline $\begin{array}{l}\text { BP3.0 Market and Sell Products and } \\
\text { Services }\end{array}$ & S1 & Advertising / marketing \\
\cline { 2 - 3 } & S2 & Pricing strategy \\
\cline { 2 - 3 } & S3 & Promotions, discounts, loans \\
\hline BP4.0 Deliver Products and Services & S4 & Service availability and distribution channels \\
\cline { 2 - 3 } & S5 & Ordering process \\
\hline BP5.0 Manage Customer Service & S6 & Complaint handling and warranty services \\
\cline { 2 - 3 } & S7 & Customer service \\
\hline
\end{tabular}

There is a need to emphasize that the types of knowledge that are reported in Table 1 relate to just three APQC's business processes, i.e.: BP3.0 Market and Sell Products and Services; BP4.0 Deliver Products and Services; and BP5.0 Manage Customer Service. The detailed analysis of BP2.0 was presented in Ziemba et al. (2018). Thus, BP2.0 has not been included in this analysis as it involves a number of detailed knowledge types that are too broad to include in the analysis and discussion in this paper. Understanding how prosumers share their knowledge for the development of services required a modification of the APQC's business process model. The approach requires a focus on each particular type of prosumers knowledge that are associated with each of the service process stages. As a consequence, this paper aims to answer the research question of what kind of knowledge about services do Poland-based and UK-based prosumers share and would like to share? Accordingly, the objectives of the paper are threefold. Firstly, the analysis of business processes in which prosumers can share knowledge, which in turn lead us to indicating the kinds of knowledge which prosumers share about services. Secondly, perform a thorough analysis to determine what knowledge about services prosumers share and would like to share. Thirdly, investigate the different kinds of knowledge about services that prosumers share and would like to share, as well as considering the statistically significant differences between Poland-based and UK-based prosumers.

The paper is organized as follows: the research questions and hypotheses followed by the research methodology; then results, analysis, and discussion are provided; and the paper concludes with a summary, limitations, and avenues for future research.

\section{Research Questions and Hypotheses}

Previous research studies show that prosumers can share knowledge about products and at the same time have an impact on development of products (Ziemba \& Eisenbardt, 2015a, 2015b) but 
the results were from Poland-based prosumers only. The extensive review of the literature, did not uncover any detailed studies concerning business processes development, especially services development, and prosumers' knowledge sharing. What is more, the scope of the literature does not focus on different countries comparisons in relation to the service process stages. The research among Poland-based and UK-based prosumers aims to improve our understanding of prosumers' knowledge sharing for service development.

The aim of the study is to determine which kinds of knowledge are Poland-based and UK-based prosumers sharing and which kinds of knowledge would they like to share about enterprise service processes?

The study tests whether there are statistically significant differences between knowledge about services that Poland-based and UK-based prosumers share, and similarly whether there are statistically significant differences between knowledge about services that Poland-based and UKbased prosumers would like to share. In practical terms, enterprises gain new insight from these findings with specific reference to Poland-based and UK-based prosumers knowledge sharing about services what may help them to make decisions about which projects and activities they can engage with prosumers for future knowledge sharing. The study was designed around three main questions each consisting of two sub-questions. The study questions:

RQ1: Are there statistically significant differences in knowledge about services that Polandbased and UK-based prosumers (combined) share and would like to share?

RQ1a: What knowledge about services do Poland-based and UK-based prosumers (combined) share?

RQ1b: What knowledge about services would Poland-based and UK-based prosumers (combined) like to share?

RQ2: Are there statistically significant differences in knowledge about services that Polandbased and UK-based prosumers share?

RQ2a: What knowledge about services do Poland-based prosumers share?

RQ2b: What knowledge about services do UK-based prosumers share?

RQ3: Are there statistically significant differences in knowledge about services that Polandbased and UK-based prosumers would like to share?

RQ3a: What knowledge about services would Poland-based prosumers like to share?

RQ3b: What knowledge about services would UK-based prosumers like to share?

Taking into account all above considerations and the above research questions, three research hypotheses were formulated:

H1: There are statistically significant differences in knowledge about services that Polandbased and UK-based prosumers (combined) share and would like to share.

H2: There are statistically significant differences in knowledge about services that Polandbased and UK-based prosumers share. 
H3: There are statistically significant differences in knowledge about services that Polandbased and UK-based prosumers would like to share.

Figure 1 depicts the graphical combination of research questions with research hypotheses posed for knowledge sharing about services for a number of business process stages.

\begin{tabular}{|c|c|c|}
\hline $\begin{array}{l}\text { RQ1 } \\
\text { RQ1a } \\
\text { RQ1b }\end{array}$ & H1 & Main research question: \\
\hline $\begin{array}{l}\text { RQ2 } \\
\text { RQ2a } \\
\text { RQ2b }\end{array}$ & $\mathrm{H} 2$ & $\begin{array}{l}\text { What kinds of knowledge } \\
\text { about services do Poland- } \\
\text { based and UK-based }\end{array}$ \\
\hline $\begin{array}{l}\text { RQ3 } \\
\text { RQ3a } \\
\text { RQ3b }\end{array}$ & $\mathrm{H} 3$ & $\begin{array}{l}\text { prosumers share and } \\
\text { would like to share? }\end{array}$ \\
\hline
\end{tabular}

Figure 1. Graphical Combination of the Research Questions with Research Hypotheses

The figure also shows that each posited hypothesis was supported by three research questions, each of the three research questions contained two sub-questions. That approach enabled us to confirm or to reject the hypotheses and as a result led us to answer the main research question.

\section{Research Methodology}

Research methods included a critical review of the literature, logical deduction, case studies, a survey questionnaire, and statistical analysis. The research process included the following steps:

LITERATURE: A critical review of existing studies related to 'prosumption', 'prosumer', 'customer', 'consumer', 'knowledge sharing', 'business processes', and 'services' enabled examination of prosumers knowledge sharing to develop and manage services. The review embraces four bibliographic databases: Ebsco, ProQuest, Emerald Management, and ISI Web of Knowledge. In addition, some journals and Web materials dedicated to research on 'consumption' and 'prosumption' were also explored.

CASE STUDIES: Case studies of prosumers' knowledge sharing indicated that prosumers can share their knowledge and at the same time they can develop and manage services (Ziemba \& Eisenbardt, 2015a). Based on the analysis of literature, as well as the analysis of the abovementioned case studies, the specific kinds of knowledge which they can share about services were proposed.

PILOT: An initial pilot questionnaire was designed in Polish and translated into English for the UK participants. The English translation was undertaken in Poland and the questionnaire was evaluated and pretested with colleagues and a sample of respondents in the UK University to 
determine suitability and appropriateness for the survey. The questionnaire was divided into two parts. After a few demographics questions all participants were obliged to answer the question: Have you ever assessed or commented on products or companies, proposed products improvements to the companies or designed new products? This question enabled the division of respondents into consumers (not active in this matter) and prosumers (active ones). The questionnaire contained questions concerning specified kinds of knowledge that prosumers can share. The questions were: (1) Please indicate, what were your assessments or comments on services or proposals for developments of services? (2) If you could in a free and unlimited way share your knowledge about services, propose ideas of service developments or ideas for the design of new services - please indicate what would your proposals be concerned with? The pilot questionnaire was directed only to prosumers. The final questionnaire was directed to both - prosumers and consumers. The pilot data was not included with the final dataset for analysis. The kinds of knowledge about services were listed for these questions (see Table 1). For each listed kind of knowledge the respondents could choose one of five responses, according to a 5point Likert scale: (1) definitely no, (2) rather no, (3) neither yes nor no, (4) rather yes, (5) definitely yes. In November 2014 the more in-depth pilot survey was conducted in Poland. The purpose was substantive and methodological scrutiny of the questionnaire. To conduct reliability analysis, Cronbach's coefficient alpha was used. For all analyzed items the Cronbach's alpha was 0.785 . According to Hinton (2004) it can be concluded that the scale had acceptable to good reliability, and it could be used in the research process. Moreover, substantive scrutiny of the questionnaire enabled to perform minor changes to improve the quality of the questionnaire.

CAWI: Applying the Computer-Assisted Web Interview (CAWI) method and employing the Poland platform Ankietka.pl, and the UK platform Bristol Online Survey (BOS), hosted at the University of Bristol, the questionnaire was uploaded to the website. Data collection took place between the end of December 2014 and March 2015 in Poland, and between February and April 2016 in the United Kingdom.

SAMPLE: In Poland, the designed sample size was 2,500 people, comprising people of different age, gender, and Information and Communications Technologies (ICT) skills. In the UK the online survey letter and URL was initially posted to 1,000 individuals comprising people of different age, gender, and ICT skills, and presented to a random sample of the target population. Using online tools permits contact with an accessible audience as the survey appears on search engine lists due to metatags and appropriate placing of keywords. After screening the responses and excluding outliers, there was a final research sample of 783 usable, correct and complete questionnaires from Poland and 171 from the United Kingdom. The data was stored in Microsoft Excel format. The demographic analysis of the research sample is presented in Table 2. The demographics provide a description of the characteristics of individuals who engage in the prosumer process.

The demographics for the Poland-based and UK-based respondents vary in terms of age. Whereas $79.9 \%$ of Poland-based respondents fall into $\mathrm{Y}$ and $\mathrm{Z}$ generation categories, only $41.52 \%$ of UK-based respondents are younger than 35 years. The level of education in the UKbased respondents is at a higher level than the Poland-based respondents. There are no main differences in the respondents' place of residents. 
Table 2. Demographic Analysis of the Research Sample

\begin{tabular}{|c|c|c|c|c|}
\hline \multirow[b]{2}{*}{ Demographic profile } & \multicolumn{2}{|c|}{ Poland } & \multicolumn{2}{|c|}{ United Kingdom } \\
\hline & $\begin{array}{l}\text { Number of } \\
\text { respondents }\end{array}$ & Percentage & $\begin{array}{l}\text { Number of } \\
\text { respondents }\end{array}$ & Percentage \\
\hline \multicolumn{5}{|l|}{ Gender } \\
\hline Female & 599 & $76.5 \%$ & 98 & $57.3 \%$ \\
\hline Male & 184 & $23.5 \%$ & 73 & $42.7 \%$ \\
\hline \multicolumn{5}{|l|}{ Age } \\
\hline Builders generation: over 65 years old & 14 & $1.8 \%$ & 8 & $4.68 \%$ \\
\hline $\begin{array}{l}\text { Baby-Boomers generation: } 51-65 \text { years } \\
\text { old }\end{array}$ & 35 & $4.5 \%$ & 25 & $14.62 \%$ \\
\hline X generation: $36-50$ years old & 108 & $13.8 \%$ & 67 & $39.18 \%$ \\
\hline Y generation: $21-35$ years old & 369 & $47.1 \%$ & 68 & $39.77 \%$ \\
\hline$Z$ generation: less than 21 years old & 257 & $32.8 \%$ & 3 & $1.75 \%$ \\
\hline \multicolumn{5}{|l|}{ Level of education } \\
\hline Higher education & 217 & $27.7 \%$ & 89 & $52.05 \%$ \\
\hline Secondary education & 559 & $71.4 \%$ & 75 & $43.86 \%$ \\
\hline Less than secondary education & 7 & $0.9 \%$ & 7 & $4.09 \%$ \\
\hline \multicolumn{5}{|l|}{ Place of residence } \\
\hline $\begin{array}{l}\text { City with a population of more than } \\
100,000\end{array}$ & 419 & $53.5 \%$ & 96 & $56.14 \%$ \\
\hline $\begin{array}{l}\text { City with a population of less than } \\
100,000\end{array}$ & 244 & $31.2 \%$ & 53 & $30.99 \%$ \\
\hline Rural area & 120 & $15.3 \%$ & 22 & $12.87 \%$ \\
\hline
\end{tabular}

RELIABILITY: As the process of collecting data was completed the reliability was calculated. The Cronbach's alpha coefficient with all seven items confirmed $79 \%$ reliable variance which is deemed an "acceptable to good" reliability for internal consistency because it leaves $21 \%$ error variance. In addition, it was determined that the removal of some items would not lead to the significant improvement of internal consistency among items on the scale. Therefore, it was decided that for further analyses all seven items would be used.

STATISTICAL ANALYSES: In order to answer the research questions and confirm the research hypotheses, the statistical analysis was employed. Firstly, the descriptive analysis was employed to describe kinds of knowledge about products that prosumers share and would like to share. The following statistics were calculated: mean, median (MDN), mode, standard deviation (SD), coefficient of variation (CV), and skewness (SK). Secondly, the Mann-Whitney U test was applied in order to identify differences between Poland-based and UK-based prosumers, and between kinds of knowledge that prosumers share and would like to share. This test was selected because it does not make any assumptions related to the distribution, and it is used to test whether two independent samples of observations are drawn from the same or identical distribution. The statistical analysis was made using MS Excel and SPSS (Ver.24) software. 


\section{Research Findings}

\section{Knowledge about services that Poland-based and UK-based prosumers (combined) share and would like to share}

The following research questions and hypothesis were posed related to a comparison between knowledge about services which Poland-based and UK-based prosumers (combined) share and would like to share:

RQ1: Are there statistically significant differences in knowledge about services that Polandbased and UK-based prosumers (combined) share and would like to share?

RQ1a: What knowledge about services do Poland-based and UK-based prosumers (combined) share?

RQ1b: What knowledge about services would Poland-based and UK-based prosumers (combined) like to share?

H1: There are statistically significant differences in knowledge about services that Polandbased and UK-based prosumers (combined) share and would like to share.

In order to answer the sub-questions RQ1a and RQ1b, a detailed analysis concerning knowledge about services that Poland-based and UK-based prosumers (combined) share and would like to share was completed. The results are presented in Table 3.

Table 3. Knowledge about services that Poland-based and UK-based prosumers (combined) share

\begin{tabular}{|l|c|c|c|c|c|c|c|c|c|c|c|c|}
\hline Item & \multicolumn{4}{|c|}{ Prosumers Share Knowledge } & \multicolumn{4}{|c|}{ Prosumers Would Like to Share Knowledge } \\
& Mean & MDN & Mode & SDV & CV & SK & Mean & MDN & Mode & SDV & CV & SK \\
\hline S1 & 2.50 & 2 & 2 & 1.28 & 0.51 & 0.49 & 2.72 & 2 & 2 & 1.18 & 0.43 & 0.36 \\
\hline S2 & 2.93 & 3 & 4 & 1.36 & 0.46 & -0.07 & 3.36 & 4 & 4 & 1.23 & 0.37 & -0.42 \\
\hline S3 & 1.85 & 2 & 1 & 1.07 & 0.58 & 1.62 & 2.46 & 2 & 2 & 1.11 & 0.45 & 0.43 \\
\hline S4 & 2.90 & 3 & 4 & 1.31 & 0.45 & -0.08 & 3.35 & 4 & 4 & 1.20 & 0.36 & -0.35 \\
\hline S5 & 3.41 & 4 & 4 & 1.31 & 0.39 & -0.54 & 3.43 & 4 & 4 & 1.24 & 0.36 & -0.45 \\
\hline S6 & 3.21 & 4 & 4 & 1.35 & 0.42 & -0.32 & 3.44 & 4 & 4 & 1.24 & 0.36 & -0.43 \\
\hline S7 & 3.61 & 4 & 4 & 1.27 & 0.35 & -0.79 & 3.59 & 4 & 4 & 1.18 & 0.33 & -0.60 \\
\hline
\end{tabular}

Abbreviations used: MDN - median, SD - standard deviation, CV - coefficient of variation, and SK - skewness.

It is found in Table 3 that prosumers mainly share their knowledge about customer services (Mean=3.61; $\mathrm{MDN}=4$; Mode=4), ordering process (Mean=3.41; $\mathrm{MDN}=4$; Mode=4), and complaint handling and warranty services (Mean=3.21; MDN=4; Mode=4). Whilst they were rather reluctant or they were not encouraged by enterprises to share knowledge about promotions, discounts and loans $($ Mean=1.85; $\mathrm{MDN}=2$; Mode=1), as well as advertising and 
marketing of the service (Mean=2.50; $\mathrm{MDN}=2 ; \mathrm{Mode}=2$ ). However, it is found that prosumers would like to share knowledge more widely in the future than they are currently sharing, except for customer service (Mean=3.59; $\mathrm{MDN}=4$; Mode=4), which only saw a slight decrease, but it was the only decrease in the items considered. What is more, the greater increase in items to share knowledge about in the future are seen in S3 and S4 followed by S2 which are all associated with process 3.0. The increase in the mean values pertains to S3, followed by S4, then $\mathrm{S} 2$, indicating that there is a group of prosumers who are sharing knowledge about services, nonetheless if they have an opportunity they would like to be more engaged in knowledge sharing.

In order to answer the main RQ1 (Are there statistically significant differences between knowledge about services that Poland-based and UK-based prosumers (combined) share and would like to share?), the Mann-Whitney $U$ test was used. It was used since in this study, two independent samples were analyzed: (1) knowledge about services that prosumers share; and (2) knowledge about services that they would like to share. The analysis results presented in Table 4 show that there were significant differences $(\mathrm{p}<0.05)$ for all analyzed items except S5 and S7. More specifically, the results suggest that there are no significant differences between the current sharing processes and future opportunities to share for 'ordering processes' and 'customer service'. More people would like to get more involved in the knowledge sharing processes for advertising/marketing, pricing strategy, promotions and discounts, service availability and complaint handling.

Thus, H1 was partially supported.

Table 4. The Mann-Whitney U test results for knowledge about services that Poland-based and UK-based prosumers (combined) share and would like to share

\begin{tabular}{|l|l|c|c|}
\hline Item & Types of Service & $\mathbf{Z}$ & p value \\
\hline S1 & Advertising/marketing & -3.70 & $<0.05$ \\
\hline S2 & Pricing strategy & -5.56 & $<0.05$ \\
\hline S3 & Promotions, discounts, loans & -10.39 & $<0.05$ \\
\hline S4 & Service availability and distribution channels & -5.89 & $<0.05$ \\
\hline S5 & Ordering process & -0.18 & 0.86 \\
\hline S6 & Complaint handling and warranty services & -2.86 & $<0.05$ \\
\hline S7 & Customer service & -0.85 & 0.40 \\
\hline
\end{tabular}

It was decided to perform detailed analysis of knowledge about services that Poland-based and UK-based prosumers (combined) share as our intention was to draw a complete picture. The analysis was made using box plots. The results are presented in Figure 2 about knowledge prosumers share and knowledge prosumers would like to share. 

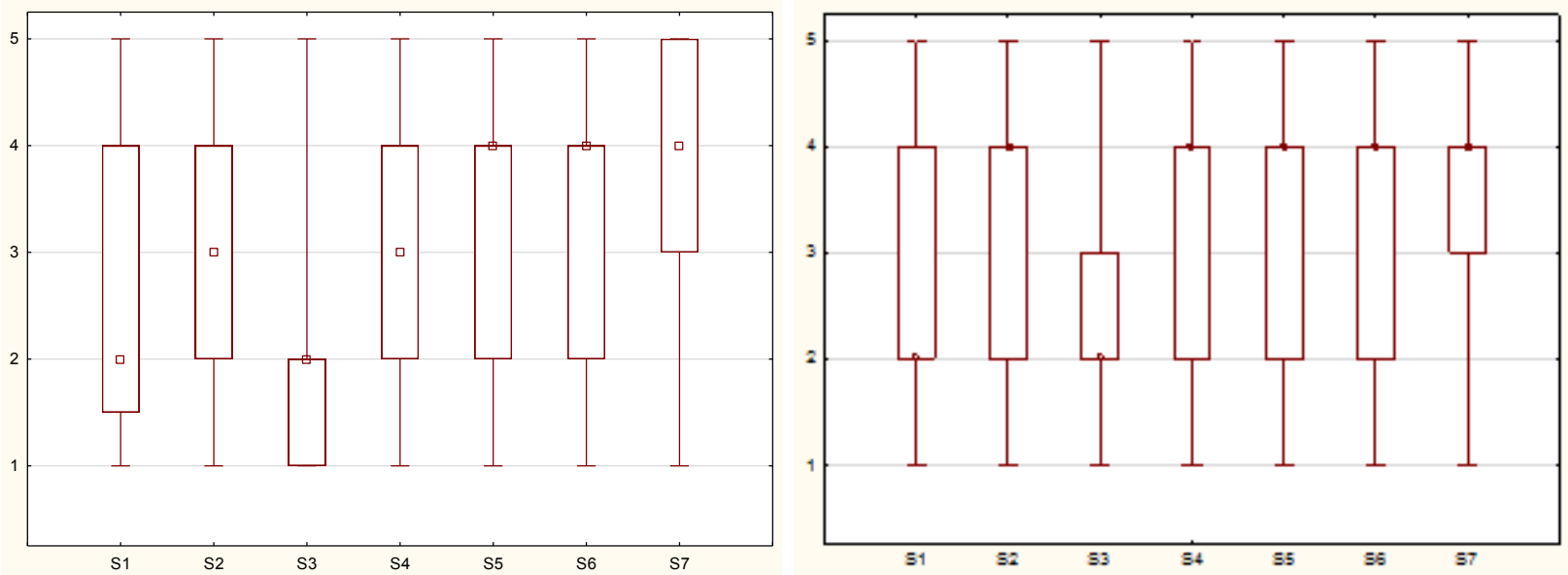

Figure 2. Knowledge About Services Which Poland-based and UK-based Prosumers (combined) Share and Would Like to Share

The box plots presented in Figure 2 show that:

- There are median differences only in the case of pricing strategy (S2) and service availability and distribution channels (S4) and the median values of (S1), (S3), (S5), (S6) and (S7) are the same for prosumers already sharing and prosumers would like to share knowledge.

- The differences between the two groups share and would like to share in the case of pricing strategy (S2) and service availability and distribution channels (S4) are also illustrated by different distributions around the median values.

- The left graph shows lower values of the first quartile Q1 (25\%) for advertising and marketing (S1) and promotions, distributions and loans (S3), but no significant differences in the distribution of values in ordering processes (S5) and complaint handling and warranty services (S6).

- In the case of customer service (S7), the third quartile Q3 (75\%) exceeds the value of 4 in the left graph. The higher values for the group sharing may suggest that there are already good opportunities to share knowledge in the area of customer services. This in turn might be explained by the fact that this service is usually an established process within a business where consumers already have the opportunity to interact with the business; hence, there is less of a perceived barrier for interaction.

- Overall, the results presented in the graphs suggest that consumers would like to share more knowledge about services.

\section{Knowledge about services that Poland-based and UK-based prosumers share}

The following research questions and hypothesis were posed related to a comparison in knowledge about services which Poland-based and UK-based prosumers share: 
RQ2: Are there statistically significant differences in knowledge about services that Polandbased and UK-based prosumers share?

RQ2a: What knowledge about services do Poland-based prosumers share?

RQ2b: What knowledge about services do UK-based prosumers share?

H2: There are statistically significant differences in knowledge about services that Polandbased and UK-based prosumers share.

In order to answer the sub-questions RQ2a and RQ2b, a detailed analysis concerning knowledge about services that Poland-based and UK-based prosumers share was completed. The results are presented in Table 5. It was found that Poland-based prosumers mainly share their knowledge about customer service (Mean=3.62; $\mathrm{MDN}=4$; Mode=4), ordering process of services (Mean=3.45; $\mathrm{MDN}=4$; Mode=4), and complaint handling and warranty services (Mean=3.20; $\mathrm{MDN}=4$; Mode=4). UK-based prosumers also engage in sharing knowledge about customer service (Mean=3.61; $\mathrm{MDN}=4$; Mode=4), ordering process of services (Mean=3.29; $\mathrm{MDN}=4$; Mode=4), and complaint handling and warranty services (Mean=3.26; $\mathrm{MDN}=4$; Mode=4), so we found in our study very similar kinds of engagement in knowledge sharing. On the other hand, the results clearly show that in general UK-based prosumers are reluctant to share certain kinds of knowledge - the median and mode values are 2s, for (S1-S4), taking part in marketing campaigns, influencing service price, influencing promotions, discounts or loan programs, and influence services availability and new distribution channels which means that they would rather share knowledge about these service. The general analysis of the results shows that Poland-based prosumers share knowledge marginally more than UK-based ones. In order to answer the main RQ2 (Are there statistically significant differences in knowledge about services that Polandbased and UK-based prosumers share?), the Mann-Whitney U test was used. It was used since there were two independent samples: (1) Poland-based, and (2) UK-based prosumers. The test results presented in Table 6 show no significant differences between

Table 5. Knowledge About Services that Poland-based and UK-based Prosumers Share

\begin{tabular}{|l|c|c|c|c|c|c|c|c|c|c|c|c|}
\hline \multirow{2}{*}{ Item } & \multicolumn{4}{|c|}{ Poland Prosumers } & \multicolumn{5}{c|}{ UK-based Prosumers } \\
& Mean & MDN & Mode & SDV & CV & SK & Mean & MDN & Mode & SDV & CV & SK \\
\hline S1 & 2.58 & 2 & 2 & 1.41 & 0.54 & 0.34 & 2.09 & 2 & 2 & 0.80 & 0.40 & 1.89 \\
\hline S2 & 3.01 & 3 & 4 & 1.38 & 0.46 & -0.18 & 2.55 & 2 & 2 & 1.15 & 0.47 & 0.57 \\
\hline S3 & 1.77 & 1 & 1 & 0.99 & 0.56 & 1.31 & 2.29 & 2 & 2 & 1.11 & 0.58 & 0.80 \\
\hline S4 & 3.01 & 3 & 4 & 1.30 & 0.43 & -0.17 & 2.45 & 2 & 2 & 1.08 & 0.50 & 0.54 \\
\hline S5 & 3.45 & 4 & 4 & 1.31 & 0.38 & -0.57 & 3.29 & 4 & 4 & 1.26 & 0.41 & -0.37 \\
\hline S6 & 3.20 & 4 & 4 & 1.36 & 0.42 & -0.31 & 3.26 & 4 & 4 & 1.25 & 0.40 & -0.26 \\
\hline S7 & 3.62 & 4 & 4 & 1.27 & 0.35 & -0.75 & 3.61 & 4 & 4 & 1.19 & 0.35 & -0.94 \\
\hline
\end{tabular}

Abbreviations used: MDN - median, SD - standard deviation, CV - coefficient of variation, and SK - skewness. 
Poland-based and UK-based prosumers in relation to three items: customer service, ordering process of services and complaint handling and warranty services. Whereas there were significant differences in taking part in influencing advertising and marketing of services, service price strategy, influencing promotions, discounts or loan programs, as well as influence service availability and new distribution channels. Thus, $\mathrm{H} 2$ was partially supported.

Table 6. The Mann-Whitney U Test Results for Knowledge About Services that Poland-based and UK-based Prosumers Share

\begin{tabular}{|l|l|c|c|}
\hline Item & Types of Service & $\mathbf{Z}$ & $\mathbf{p}$ value \\
\hline S1 & Advertising/marketing & -2.31 & $<0.05$ \\
\hline S2 & Pricing strategy & -2.56 & $<0.05$ \\
\hline S3 & Promotions, discounts, loans & -4.39 & $<0.05$ \\
\hline S4 & Service availability and distribution channels & -3.46 & $<0.05$ \\
\hline S5 & Ordering process & -1.02 & 0.31 \\
\hline S6 & Complaint handling and warranty services & -0.33 & 0.74 \\
\hline S7 & Customer service & -0.30 & 0.76 \\
\hline
\end{tabular}

It was decided to perform detailed analysis of knowledge about products that Poland-based and UK-based prosumers share as our intention was to gain a complete picture of the data. The analysis was conducted using box plots. The results are presented in Figure 3.
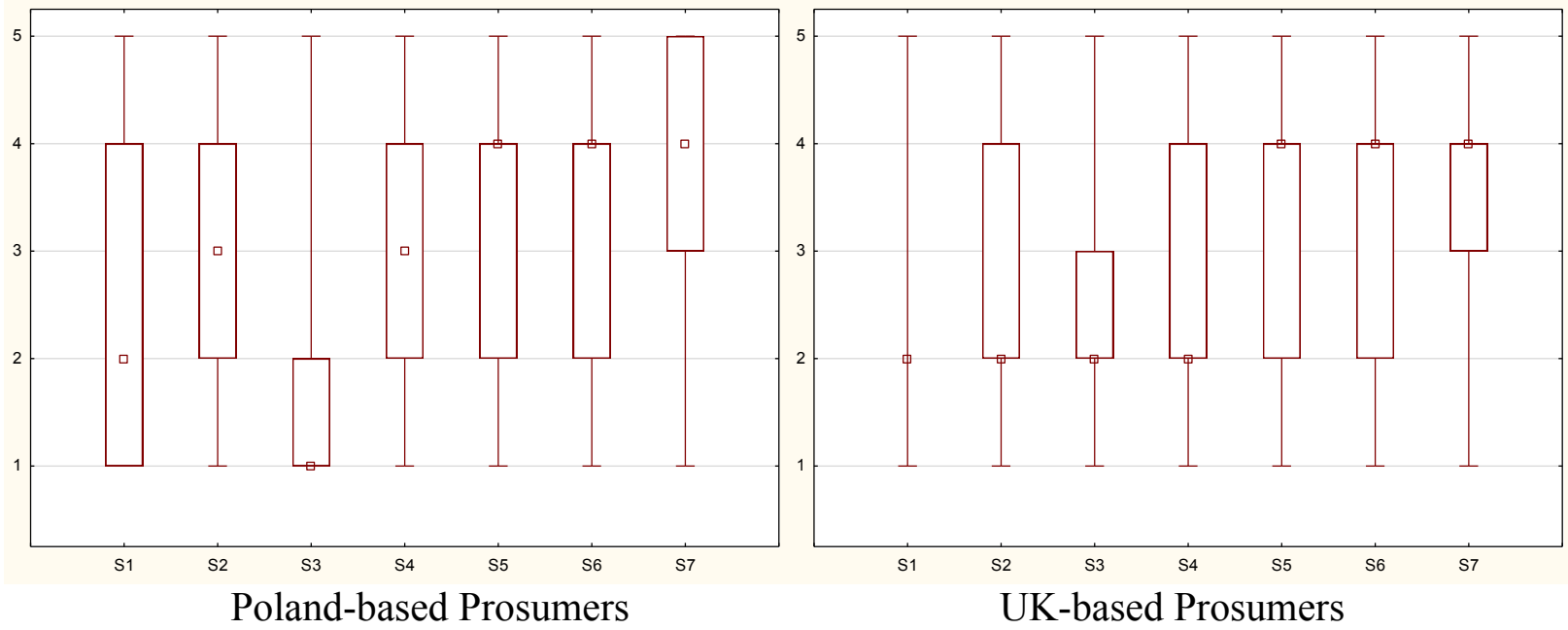

Figure 3. Knowledge About Services Which Poland-based and UK-based Prosumers Share The box plots presented in Figure 3 show that:

- There are median differences in the case of pricing strategy (S2), promotions, discounts and loans (S3) and service availability and distribution channels (S4). In these cases, Poland-based prosumers are more likely to share their knowledge in 
terms of S2 and S4, whereas UK-based prosumer share more knowledge in the case of S3. Where the median values are similar (S1, S5, S6 and S7), it is possible to observe a difference in S7, where the third quartile (Q3) shows higher values for Poland prosumers compared to UK prosumers.

\section{Knowledge about services that Poland and UK-based prosumers would like to share}

The following research questions and hypothesis related to a comparison in knowledge about services which Poland-based and UK-based prosumers would like to share were posed:

RQ3: Are there statistically significant differences in knowledge about services that Polandbased and UK-based prosumers would like to share?

RQ3a: What knowledge about services would Poland-based prosumers like to share?

RQ3b: What knowledge about services would UK-based prosumers like to share?

H3: There are statistically significant differences in knowledge about services that Polandbased and UK-based prosumers would like to share.

In order to answer the sub-questions RQ3a and RQ3b a detailed analysis concerning knowledge about services that Poland-based and UK-based prosumers would like to share was completed. The results are presented in Table 7.

Table 7. Knowledge About Services that Poland-based and UK-based Prosumers Would Like to Share

\begin{tabular}{|l|c|c|c|c|c|c|c|c|c|c|c|c|}
\hline Item & \multicolumn{4}{|c|}{ Poland Prosumers } & \multicolumn{5}{c|}{ UK-based Prosumers } \\
& Mean & MDN & Mode & SDV & CV & SK & Mean & MDN & Mode & SDV & CV & SK \\
\hline S1 & 2.84 & 3 & 2 & 1.25 & 0.44 & 0.16 & 2.18 & 2 & 2 & 0.94 & 0.43 & 1.54 \\
\hline S2 & 3.52 & 4 & 4 & 1.17 & 0.33 & -0.57 & 2.63 & 2 & 2 & 1.22 & 0.46 & 0.26 \\
\hline S3 & 2.46 & 2 & 2 & 1.09 & 0.44 & 0.42 & 2.45 & 2 & 2 & 1.18 & 0.48 & 0.44 \\
\hline S4 & 3.52 & 4 & 4 & 1.14 & 0.32 & -0.54 & 2.58 & 2 & 2 & 1.17 & 0.47 & 0.39 \\
\hline S5 & 3.45 & 4 & 4 & 1.23 & 0.36 & -0.40 & 3.33 & 4 & 4 & 1.29 & 0.39 & -0.63 \\
\hline S6 & 3.48 & 4 & 4 & 1.24 & 0.36 & -0.46 & 3.26 & 4 & 4 & 1.19 & 0.36 & -0.35 \\
\hline S7 & 3.66 & 4 & 4 & 1.17 & 0.32 & -0.65 & 3.30 & 4 & 4 & 1.17 & 0.35 & -0.42 \\
\hline
\end{tabular}

Abbreviations used: MDN - median, SD - standard deviation, $\mathrm{CV}$ - coefficient of variation, and SK - skewness.

It is found that in general Poland-based prosumers would like to share their knowledge. Their willingness to share knowledge refers especially to complaint handling and warranty services $(\mathrm{Mean}=3.66 ; \mathrm{MDN}=4$; $\mathrm{Mode}=5)$, service availability and distribution channels (Mean=3.52; $\mathrm{MDN}=4$; Mode=4), as well as pricing strategy (Mean=3.52; MDN=4; Mode=4). This is 
interesting as these results show more interest from Poland-based prosumers to share knowledge in the future especially in item S2 and S4. On the other hand, UK-based prosumers are particularly reluctant to share knowledge about S2 and S4 and in this process, BP3.0 in Table 1 the majority of the median and mode values are 2 , which means that they would not like to engage with enterprises in the future to share knowledge about services. If they do engage with enterprises they suggest that they would like to share knowledge about the ordering process (Mean=3.33; MDN=4; Mode=4) followed by customer service (Mean=3.30; MDN=4; Mode=4) and complaint handling and warranty services (Mean=3.26; MDN=4; Mode=4). Nonetheless, the general analysis of the results shows that Poland prosumers would like to share knowledge more widely than UK-based ones. The mean for all items, to engage prosumers in future knowledge sharing saw an increase for Poland-based prosumers while the mean for all items showed a decrease for UK prosumers. This can be interpreted as a very definite set of responses.

In order to answer the main RQ3 (Are there statistically significant differences in knowledge about the services that Poland-based and UK-based prosumers would like to share?), the MannWhitney U test was used since there are two independent samples: (a) Poland-based, and (b) UKbased prosumers. The test results presented in Table 8 show that there were no significant differences for service promotions, discounts and loans and also the service ordering process. Whereas there were significant differences in the case of five of the items, service availability and distribution channels, pricing strategy, advertising/marketing, customer service and complaint handling and warranty services. Thus, H3 was partially supported.

Table 8. The Mann-Whitney U Test Results for Knowledge About Services that Poland-based and UK-based Prosumers Would Like to Share

\begin{tabular}{|l|l|c|c|}
\hline Item & Types of Service & $\mathbf{Z}$ & p value \\
\hline S1 & Advertising/marketing & -7.02 & $<0.05$ \\
\hline S2 & Pricing strategy & -8.22 & $<0.05$ \\
\hline S3 & Promotions, discounts, loans & -0.46 & 0.64 \\
\hline S4 & $\begin{array}{l}\text { Service availability and distribution } \\
\text { channels }\end{array}$ & -8.85 & $<0.05$ \\
\hline S5 & Ordering process & -0.88 & 0.38 \\
\hline S6 & Complaint handling and warranty services & -2.17 & $<0.05$ \\
\hline S7 & Customer service & -3.71 & $<0.05$ \\
\hline
\end{tabular}

It was decided to perform a detailed analysis of knowledge about services that Poland-based and UK-based prosumers would like to share as our intention was to draw a complete picture in that matter. The analysis was made using box plots. The results are presented in Figure 4. 


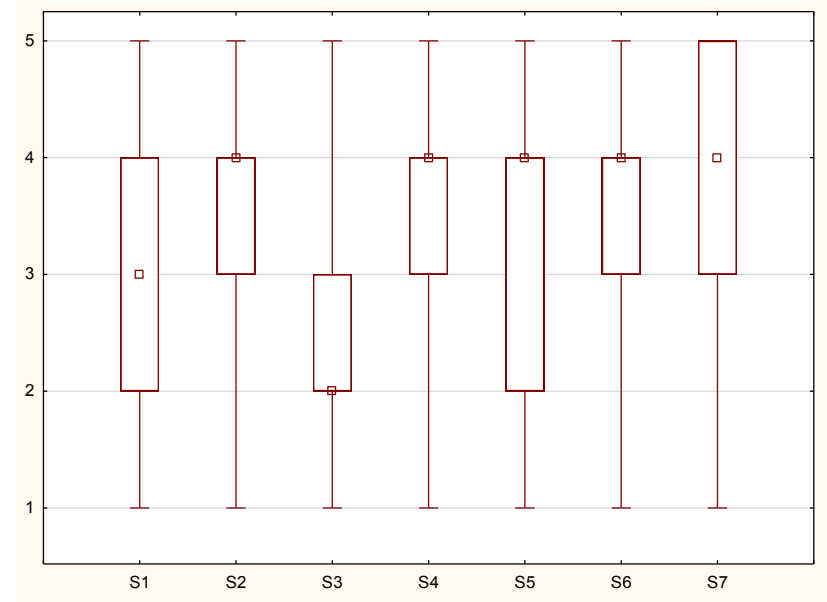

Poland-based Prosumers

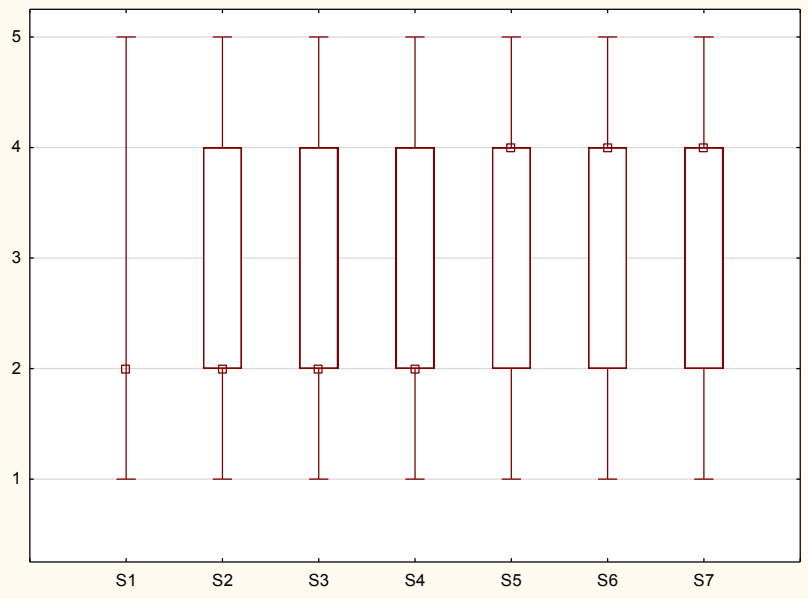

UK-based Prosumers

Figure 4. Knowledge About Products Which Poland-based and UK-based Prosumers Would Like to Share

The box plots presented in Figure 4 show that,

- The median values are different in advertising and marketing (S1), pricing strategy (S2) and service availability and distribution channels (S4). In all these cases, the results suggest that Poland-based prosumers would like to share knowledge to a greater extent than UK prosumers.

- Where the median values are the same (S3, S5, S6, \& S7), the results suggest a slight tendency for a greater contribution of the Poland-based prosumers compared to the UK prosumers for S6 and S7. For S6, the values of the lower quartile Q1 are between 3 and 4 for Poland-based prosumers (between $2 \& 4$ for UK consumers) and the third quartile Q3 goes beyond the value of 4 for S7. This only contrasts for S3, where the third quartile (Q3) spreads out to the value of 4 for UK-based prosumers compared to the value of 3 for Poland-based prosumers.

\section{Discussion of Research Findings}

Authors such as Bilstein (2011) recognized that customers are an integral part of the service process, and as such the AQPC model provided a useful framework for each of the service process stages. The framework also may be considered as a guide to examine those areas where prosumers engage most at the present time and where they intend to engage most in sharing knowledge about service process in the future. It is interesting to also view those present and future knowledge sharing stages that indicate less engagement or less customer integration as referred to by Möller (2008), as those are areas where process innovations need to be boosted to meet customer needs, desires and future preferences. 
The combined country results indicated that prosumers are willing to share knowledge about services to a greater extent in the future and there are particular increases in items to associate with S3, S4 followed by S2 which are all connected with process, BP3.0 in Table 1. As the younger generations grow more used to social media activity they are likely to continue to impact on enterprises through their active knowledge sharing and may results in a further continuation of these types of consumption practices (Belk, 2014). Interestingly prosumers in both countries are equally keen on sharing knowledge about the ordering process (S5) and equally neutral about sharing knowledge regarding promotions (S3).

Engaging in knowledge sharing in process BP3.0 market and sell services including service availability and distribution channels and pricing strategy were more important to Poland-based prosumers in the future but were not rated as important by the UK-based prosumers.

Less of a difference was seen in process BP4.0 between ordering and customer services between the two sampled countries. Interestingly there is less of a difference between Poland-based and UK-based prosumers in their knowledge sharing associated with process BP4.0, the service order process and process BP5.0, managing the customer services. This is where there is agreement in the overall results in the process knowledge that Poland-based and UK-based prosumers are willing to share with enterprises. Taking ownership of the process will be more common in the future and authors such as, Botsman and Rogers (2010) advocated that rethinking ownership through collaborative consumption will be a major part of modern enterprise practice and even a new business paradigm.

These results hints to those areas where enterprises need to continue to strengthen communication with consumers to engage them in knowledge sharing in service process stages. Currently the results support the need that Poland-based and UK-based prosumers have to engage with enterprises to share knowledge relevant to process BP4.0, the service order process and process BP5.0, managing the customer services. The Poland-based and UK-based prosumers' engagement in the earlier stages is not considered with the same enthusiasm at the present time. This suggests the consumers are more interested in engaging in the services processes that are closer to the downstream activities. This starting point makes practical and economic sense as a recommendation for the enterprises to engage in knowledge sharing about services.

The Poland-based prosumers results were on average higher for future engagement in knowledge sharing for all items, yet the UK-based prosumer results were on average lower for future knowledge sharing for all items. This is an interesting finding and perhaps this suggests that UKbased prosumers do not feel the enterprises are responding to their needs and preferences. On the other hand, it may suggest that Poland-based prosumers are keener to share knowledge than UKbased ones. Furthermore, it may be that Polish prosumers feel closer to local producers, while the British, dealing with multinational enterprises are feeling less affiliated and less inclined to commit to knowledge sharing. What is more, the cultural differences may have an impact on data obtained and results presented (Anantatmula, 2010; Hofstede, 2019). The approach to the knowledge and its value vary because of the cultural differences between Poland-based and UKbased prosumers. Furthermore, it is also about knowledge itself, and knowledge sharing as well as about prospective benefits and expectations. 
The different results between UK-based and Poland-based prosumers may also be explained by the different economic and political history of both countries. Since the collapse of the Soviet Union, an increased level of consumerism could be observed in Poland as consumers for the first time could clearly identify their needs themselves and within their role as consumers the market responded to their demand. Whereas during the communist era, the state was in the power to make decisions for the Polish population. The production on capital goods had priority over the individual consumer demand and the transition from a centrally planned economy to a free market economy only happened in 1990.

The results show that Poland-based prosumers feel empowered by given the opportunity to provide feedback in the future and to actively take part in service process associated with BP3.0, BP4.0 and BP5.0 as their interests were mainly ignored by the productivist ideology of the past (Mazurek \& Hilton, 2007).

In contrast, the consumer industry in the UK gained significant importance as part of the national economy already during the 1920s. Associated with this were increased living standards and access to a large variety of consumer goods. Consumers being part of a free-market economy experience market response to a shift in consumer demands. As a result, UK consumers do not feel the same urge to actively get involved in prosumer processes as Polish consumers do and would to like to share knowledge about services especially related to the final stages of service processes such as BP5.0.

To speculate further on the results, the UK consumers have experienced years of good economic growth and customer demand at the heart of enterprise practice yet the customer's may not feel the benefit from their involvement in the service process stages. Thus, from that perspective our results correspond to Chang and Taylors' (2016) analysis who revealed that the benefits of involving customers in the idea generation and launch stages of a new products development are greater in emerging countries which Poland can be still considered.

\section{Summary and Conclusions}

\section{Research Contribution}

This work contributes to extant research on prosumers engagement in knowledge sharing by:

- Indicating the cultural knowledge sharing differences between prosumers in countries such as Poland and UK.

- Addressing the kinds of knowledge that Poland-based prosumers share and are willing to share in the future;

- Addressing the kinds of knowledge that UK-based prosumers share and are willing to share in the future; and

- Identifying significant association between kinds of knowledge preferences of Polandbased prosumers that are positively part of the development process and a limited kind of knowledge that UK-based prosumers would engage in the development process with enterprises in the future. 
The results revealed partial support for three of the formulated hypotheses $(\mathrm{H} 1, \mathrm{H} 2, \& \mathrm{H} 3)$ (Table 9).

Table 9. Summary of Hypotheses Tests

\begin{tabular}{|l|l|}
\hline Hypotheses & Findings \\
\hline $\begin{array}{l}\text { H1: There are statistically significant differences in knowledge about } \\
\text { services that Poland and UK prosumers (combined) share and would } \\
\text { like to share }\end{array}$ & Partially supported \\
\hline $\begin{array}{l}\text { H2: There are statistically significant differences in knowledge about } \\
\text { services that Poland and UK prosumers share }\end{array}$ & Partially supported \\
\hline $\begin{array}{l}\text { H3: There are statistically significant differences in knowledge about } \\
\text { services that Poland and UK prosumers would like to share }\end{array}$ & Partially supported \\
\hline
\end{tabular}

The test results explain the differences between the Poland-based and UK-based prosumers in their knowledge sharing experiences at present and in the future. The differences in the services offered at each stage in the business process model align to the expectations and future intentions of prosumers, which can in turn inform the customer service strategies (Hagel, 1999; Litvin, Goldsmith, \& Pan, 2008) at each of the stages outlined in the APQC framework.

\section{Implication for Research and Practice}

This study can be useful for researchers. They may use this methodology and do similar analyses with different samples in Poland, the UK, and other countries, additionally many comparisons between different groups and countries can be made. Moreover, the methodology constitutes a very comprehensive basis for identifying the kinds of knowledge that can encourage prosumers to engage in knowledge sharing, but researchers may develop, verify and improve this methodology and its implementation. In addition, researchers may use these research findings and employ them in studies of enterprises. Furthermore, for practitioners, the results of this study can be used to target the kinds of knowledge that align closely to the business processes and optimise the decision outputs gained through knowledge sharing.

\section{Limitation and Future Research}

The study also has some limitations. The selection of survey respondents needs to be considered in light of the results, as they indicated that the majority of the respondents were young individuals below 35 years of age in Poland. In this case it is advisable to extend the research study to widen the age participation, and it would be useful to broaden the study to research elderly individuals, such as prosumers above age 50 years.

A second limitation relates to the methodology approach. The current study considered prosumer's only rather than broadening the study to include enterprises. An intention will be to include enterprises in a further study. 
A third limitation relates to bias, as the original survey was designed in Polish and translated into English there may be some issues to address regarding the technical language which may be viewed as complex or consisting of uncommon words which then affect how the respondent's interpret the question. A pilot questionnaire was completed in the UK and questions were amended, and the vertical response scale was used to provide lists of response options as this reduces confusion from respondents. However, translation often results in a language bias that may affect the results. Further research will address the effect of common language where technical jargon can be reworded and sentences rephrased so as to limit the nature of ambiguous questions.

\section{References}

Aghamirian, B., Dorri, B., \& Aghamirian, B. (2013). Effects of customer knowledge management's eight factors in e-commerce. Management Science and Engineering, 7(4), $1-11$.

Anantatmula, V. S. (2010). Impact of cultural differences on knowledge management in global projects. VINE Journal of Information and Knowledge Management Systems, 40(3-4), 239-253. https://doi.org/10.1108/03055721011071377

APQC. (2016). Process classification framework [online]. Houston, TX: American Productivity and Quality Center. Retrieved from http://www.apqc.org/pcf

Belk, R. (2014). You are what you can access: Sharing and collaborative consumption online. Journal of Business Research, 67, 1595-1600.

Bendapudi, N., \& Leone, R.P. (2003), Psychological implications of customer participation in co-production, Journal of Marketing, 67(1), 14-28.

Bilstein, N. (2011). Co-production in the service production and delivery process conceptualization and future research fields. In: Fließ S. (eds) Beiträge zur Dienstleistungsmarketing-Forschung, pp. 97-119. Gabler. https://doi.org/10.1007/978-38349-6592-9 5

Botsman, R., \& Rogers, R. (2010). What's mine is yours: The rise of collaborative consumption. New York, NY: Harper Collins.

Brabham, D. C. (2012). Motivations for participation in a crowdsourcing application to improve public engagement in transit planning. Journal of Applied Communication Research, $40(3), 307-328$.

Brodie, R. J., Llic, A., Juric, B., \& Hollebeek, L. (2013). Consumer engagement in a virtual brand community: An exploratory analysis. Journal of Business Research. 66(1), 105114.

Bylok, F. (2013). Konsumpcja, konsument i społeczeństwo konsumpcyjne we wspótczesnym świecie [Consumption, the consumer and the consumer society in the modern world]. Katowice: Śląsk. 
Calosci, A. (2017). Places, communities and knowledge. You'll be part of an upcoming exhibition. The Design Journal, 20(1), 3393-3400. https://doi.org/10.1080/14606925 .2017 .1352843

Chang, W. \& Taylor, S. A. (2016). The effectiveness of customer participation in new product development: A meta-analysis. Journal of Marketing, 80(1), 47-64. https://doi.org/10. 1509/jm.14.0057

Chesbrough, H. W. (2006). Open innovation: The new imperative for creating and profiting from technology. Cambridge, MA: Harvard Business Press.

Cui, A. S., \& Wu, F. (2015). Utilizing customer knowledge in innovation: antecedents and impact of customer involvement on new product performance. Journal of the Academy of Marketing Science, March, 1-23. https://doi.org/10.1007/s11747-015-0433-x

De Long, D. W. (1997). Building the knowledge-based organisation: How culture drives knowledge behaviors. Boston, MA: Center for Business Innovation, Ernst \& Young LLP.

Fine, M. B., Gironda, J., \& Petrescu, M. (2017). Prosumer motivations for electronic word-ofmouth communication behaviors. Journal of Hospitality and Tourism Technology, 8(2), 280-295. https://doi.org/10.1108/JHTT-09-2016-0048

Geri, N., Gafni, R., \& Bengov, P. (2017). Crowdsourcing as a business model: Extrinsic motivations for knowledge sharing in user-generated content websites. Journal of Global Operations and Strategic Sourcing 10(1), 90-111. https://doi.org/10.1108/JGOSS-052016-0018

Gerhardt, W. (2008). Prosumers: A new growth opportunity. Cisco Internet Business Solutions Group (IBSG). Cisco Systems, Inc.

Glisby, M., \& Holden, N. (2003). Contextual constraints in knowledge management theory: The cultural embeddedness of Nonaka's knowledge-creating company. Knowledge and Process Management, 10(1), 29-36.

Gold, A. H., Malhotra, A., \& Segars, A. H. (2001). Knowledge management: An organizational capabilities perspective. Journal of Management Information Systems, 18(1), 185-214.

Groh, G., Brocco, M., \& Asikin, Y. A. (2010). Contribution awareness and fame in open innovation network's. In Hafkesbrink, J., Hoppe, H.-U., \& Schlichter, J. (eds.), Competence Management for Open Innovation - Tools and IT-support to unlock the potential of Open Innovation, pp. 115-138. Lohmar-Koln: Josef Eul Verlag.

Hafkesbrink, J., \& Evers, J. (2010). Innovation 3.0: Embedding into community knowledge - The relevance of trust as enabling factor for collaborative organizational learning. XXI ISPIM Conference Bilbao, The Dynamics of Innovation.

Hafkesbrink, J., \& Schroll, M. (2010). Organizational competences for open innovation in small and medium sized enterprises of the digital economy'. In Hafkesbrink, J., Hoppe, H.-U., \& Schlichter, J. (eds.), Competence Management for Open Innovation - Tools and ITsupport to unlock the potential of Open Innovation, pp. 21-52. Lohmar-Koln: Josef Eul Verlag. 
Hagel, J. (1999). Net gain: Expanding markets through virtual communities. Journal of Interactive Marketing, 13(1), 55-65.

Hernández-Serrano, M.J., Renés-Arellano, P., Graham, G., Greenhill, A. (2017). From prosumer to prodesigner: Participatory news consumption. Comunicar, 25(50), 77-87.

Hinton, P. (2004). Statistics explained: A guide for social science students. New York, NY: Routledge.

Hofstede, G. (2019). Country comparison. Retrieved from https://www.hofstede-insights.com/ country-comparison/poland, the-uk/

Huang, N., Burtch, G., Hong, Y., \& Polman, E. (2016). Effects of multiple psychological distances on construal and consumer evaluation: A field study of online reviews. Journal of Consumer Psychology, 26(4), 474-482. https://doi.org/10.1016/j.jcps.2016.03.001

Kayworth, T., \& Leidner, D. (2003). Organizational culture as a knowledge resource. In: C.W. Holsapple (Ed.), Handbook on Knowledge Management, 1, pp. 235-252. Berlin: Springer.

Litvin, S. W., Goldsmith, R. E., \& Pan, B. (2008). Electronic word-of-mouth in hospitality and tourism management. Tourism Management, 29(3), 458-468.

Löcker, A. K., Eraßme, D., Jakobs, E. M., Schaar, A. K., Valdez, A. C., \& Ziefle. M. (2014). Yet another platform? Motivational factors for using online communities in business contexts. Proceedings of the 5th International Conference on Applied Human Factors and Ergonomics AHFE 2014, pp. 1145-1156, Krakow, Poland.

Lusch, R. F., \& Vargo, S. L. (2006). Service-dominant logic: Reactions, reflections, and refinements. Marketing Theory, 6(3), 281-88.

Möller, S. (2008). Customer integration a key to an implementation perspective of service provision. Journal of Service Research, 11(2), 197-210.

Nonaka, I., \& Takeuchi, H. (2000). Kreowanie wiedzy w organizacji [Knowledge creation in organizations]. Warszawa: Poltext Press.

Osterwalder, A. \& Pigneur, Y. (2002). An eBusiness model ontology for modeling eBusiness. Proceedings of the 15th Bled Electronic Commerce Conference, Bled, Slovenia.

Osterwalder, A, \& Pigneur, Y. (2013). Business model generation: A handbook for vusionaries, game changers and challengers. Oxford: John Wiley and Sons.

Payne, A. F., Storbacka, K., \& Frow, P. (2008). Managing the co-creation of value. Journal of the Academy of Marketing Science, 36(1), 83-96.

Piller, F. (2008). Interactive value creation with users and customers. Retrieved from http://www.mass-customization.de/download/piller_2008-pribilla.pdf

Pine, B. J., Peppers, D., \& Roggers. M. (1995). Do you want to keep your customers forever? Harvard Business Review, 73(2), 103-114. 
Planells, A. J. (2015). Video games and the crowdfunding ideology: From the gamer-buyer to the prosumer-investor. Journal of Consumer Culture, 17(3), 620-638. https://doi.org/10. $1177 / 1469540515611200$

Prahalad, C. K., \& Ramaswamy, V. (2004). Co-creation experiences: The next practice in value creation. Journal of Interactive Marketing, 18(3), 5-14.

Rayna, T., \& Striukova, L. (2016). Involving consumers: The role of digital technologies in promoting 'prosumption' and user innovation. Journal of the Knowledge Economy, 1-20. https://doi.org/10.1007/s13132-016-0390-8

Ritzer, G., \& Jurgenson, N. (2010). Production, consumption, prosumption: The nature of capitalism in the age of the digital 'prosumer'. Journal of Consumer Culture, 10(1), 13-36.

Song, E.-J., \& Kang, M.-S. (2016). A study on the platform of knowledge integration for customer feedback in B2C service industry. International Journal of Information and Communication Technology, 8(1), 26-36. https://doi.org/10.1504/ijict.2016.073637

Taherparvar, N., Esmaeilpour, R., \& Dostar, M. (2014). Customer knowledge management, innovation capability, and business performance: A case study of the banking industry. Journal of Knowledge Management, 18(3), 591-610.

Tapscott, D., \& Williams, A. D. (2006). Wikinomics: How mass collaboration changes everything. New York, NY: Penguin Group.

Trejo, J. M., Gutiérrez, J. S., \& Guzman, G. M. (2016). The customer knowledge management and innovation. Contaduría y Administración, 61(3), 456-477. https://doi.org/ 10.1016/j.cya.2015.11.011

Troye, V. S., Xie, C., \& Breivik, E. (2002). Trying to prosume: Toward a perspective on prosumption. Proceedings of the 31th EMAC Conference, Braga, Portugal.

Tsai, W., Tsai, M., Li, S., \& Lin, C. (2012). Harmonizing firms' knowledge and strategies with organizational capabilities. Journal of Computer Information Systems, 53(1), 23-32.

Tseng, S.-M. (2016). The effect of knowledge management capability and customer knowledge gaps on corporate performance. Journal of Enterprise Information Management, 29(1), 51-71. https://doi.org/10.1108/JEIM-03-2015-0021

Walsh, J. P., Lee, Y.-N., \& Nagaoka, S. (2016). Openness and innovation in the US: Collaboration form, idea generation and implementation. Research Policy, 45(8), 16601671. https://doi.org/10.1016/j.respol.2016.04.013

Xie, C., Bagozzi, R.P., \& Troye, S.V. (2008). Trying to prosumer: Toward a theory of consumers as co-creators of value. Journal of the Academy of Marketing Science, 36, 109-122.

Ziemba, E., \& Eisenbardt, M. (2015a). Prosumers' participation in business processes. Online Journal of Applied Knowledge Management, 3(1), 114-127.

Ziemba, E., \& Eisenbardt, M. (2015b). Examining prosumers participation in business processes. Polish Journal of Management Studies, 12(1), 219-229. 
Ziemba, E., \& Eisenbardt, M. (2017). Utilization of consumers' knowledge in organizations. In F. Marimon, M. Mas-Machuca, J. Berbegal-Mirabent, R. Bastida, (Eds.), Proceedings of the 18th European Conference on Knowledge Management ECKM 2017, 2, pp. 10841093. Barcelona, International University of Catalonia.

Ziemba, E., Eisenbardt, M., \& Mullins, R. (2017). Use of information and communication technologies for knowledge sharing by Polish and UK-based prosumers. In: Ziemba E. (ed.), Information Technology for Management: New Ideas and Real Solutions. Lecture Notes in Business Information Processing, 277, pp. 49-73. Switzerland: Springer. https://doi.org/10.1007/978-3-319-53076-5 4

Ziemba, E., Eisenbardt, M., Mullins, R. \& Grabara, D. (2018). Prosumers knowledge sharing to develop and manage products. Online Journal of Applied Knowledge Management, 6(2), 72-91.

Ziemba, E. \& Mullins, R. (2016). Identifying more about customers: the phenomenon of the switch to the knowledge exchange. Online Journal of Applied Knowledge Management, $4(1), 165-179$.

\section{Authors Biographies}

Roisin Mullins completed her Ph.D. in the development and evaluation of elearning systems, learning communities and business training systems. She is an Associate Professor at the University of Wales Trinity Saint David in the UK. She has published over 50 peer-reviewed pieces including conference papers, book chapters and international journal papers. Roisin Mullins serves on the editorial boards of several international conferences. Her research has emphasized practical solutions to technology problems or novel applications of technology, so that in addition to answering a question, the research outcomes

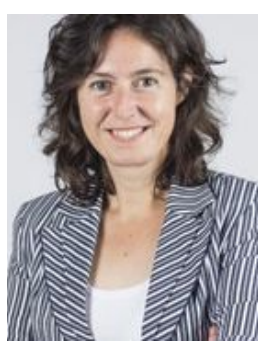
have informed policy and practice guidelines at the European level and decision making processes in the SMEs of EU member countries. She has The Award of Fellow \& Distinguished Scholar Award from the International Institute for Applied Knowledge Management, and several The Best Papers awards received at international conferences.

Monika Eisenbardt completed her Ph.D. with a major focus on management information systems as well as changes and challenges involving modern consumers. She is an Assistant Professor at the University of Economics in Katowice, Poland. She has published over 30 peer-reviewed pieces including conference papers, book chapters and international journal papers. She has received few Best Paper awards at the international conferences. Her current research focuses on consumers' knowledge and their willingness to knowledge sharing, as well as knowledge-based organizations. The background of her research is information and communication technologies. Monika serves Editorial Assistant function in Journal of Economics and Management - the official international journal of University of Economics in Katowice. She has received several Best Paper awards at the international conferences. 
Sandra Dettmer completed her Ph.D. in Labour Economics where she looked at regional disparities between earnings, unemployment and public-private sector pay across the UK. She is currently employed as a lecturer for Business and Economics at University of Wales Trinity Saint David's. Her other research interests focus on returns to education and pedagogy. Prior to her academic career, she worked in the private sector and also gained insights into business operations during her consultancy work.

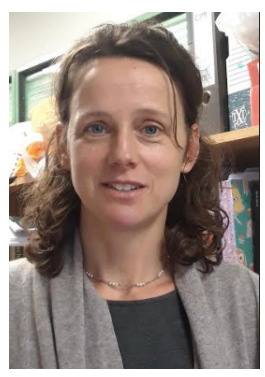

Ewa Ziemba completed her Ph.D. and Post Ph.D. in Management, with a major focus on management information systems. She is a Full Professor at the University of Economics, Katowice, Poland. Her current research focuses on information systems and technologies for business and public administration transformation. She has published over 190 peer-reviewed papers and 19 books, and has played an instrumental role in prestigious Polish and international research projects. Ewa Ziemba serves on the editorial boards of several international journals, is the Editor-in-Chief of Journal of Economics and

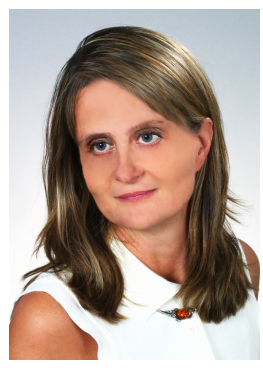
Management, the Founding Editor-in-Chief of The Online Journal of Applied Knowledge Management, the Senior Editor of Interdisciplinary Journal of Information, Knowledge, and Management, and the Editor of Interdisciplinary Journal of e-Skills and Lifelong Learning. She is also the Vice President for Research Collaborations of the International Institute for Applied Knowledge Management. Ewa Ziemba has received numerous awards for research and teaching, including The Excellent Award of the President of the University of Economics in Katowice, The Silver Cross of Merit from the President of Poland, The Medal of the National Education Commission from the Ministry of National Education in Poland, The Award of Fellow \& Distinguished Scholar and The Excellence in Research \& Scholarship Award from the International Institute for Applied Knowledge Management, and several The Best Papers awards. 